\title{
ACCOUNTING AND TAXATION OF CALCULATIONS ON CURRENT PAYMENTS TO EMPLOYEES
}

\section{ОБЛІК ТА ОПОДАТКУВАННЯ РОЗРАХУНКІВ ЗА ПОТОЧНИМИ ВИПЛАТАМИ ПРАЦІВНИКАМ}

\section{Olena Podolianchuk ${ }^{1}$}

DOI: https://doi.org/10.30525/978-9934-588-53-2-10

Abstract. Wages have always been of interest to scientists and practitioners, as it is evidenced by numerous scientific studies. It is a complex category, because it acts as an element of social and labor relations of the state, the employer and the employee. However, the problem remains the minimum wage, which leads to low productivity and, consequently, the deterioration of both economic activity and welfare. The state must comply with the rules and guarantees regarding the employee's right to receive a salary, the amount of which must meet the needs of the employee and his family members. It is not unreasonable for scientists to say that today, wages have actually become one of the options for social assistance, which depends little on the results of work.

The amount of wages depends on the complexity and conditions of work performed, the qualifications of the employee, the results of his work and economic activity of the enterprise. Therefore, each business entity organizes accounting in such a way as to be able to constantly monitor labor costs, analyze productivity, determine the tax burden on the payroll.

The object of the study is the system of accounting and taxation of payments for current payments to employees. The subject of the research is theoretical-methodical and scientific-practical principles of accounting for salary calculations and mandatory payments from it.

Theoretical and methodical bases of scientific research became general scientific and special methods: abstract-logical (for theoretical generalizations of research results and formulation of conclusions); statistical

${ }^{1}$ Candidate of Economic Sciences, Associate Professor,

Head of Accounting and Taxation Department in Economics,

Vinnytsia National Agrarian University, Ukraine 
research, in particular, comparison (to present the dynamics of average monthly wages, basic social guarantees and tax revenues to the budgets of different levels), tabular and graphical (for clarity of presentation), grouping (to summarize the results of the study), hypotheses and assumptions (to justify own opinion).

The information base of the study was the laws and regulations of Ukraine, statistical data of the State Statistics Service of Ukraine, publications in periodicals, monographs, works of domestic and foreign authors, Internet resources.

The purpose of the scientific publication is to study the economic essence of wages, the disclosure of the order of its taxation and justification of ways to improve the accounting of payments for current payments to employees.

Based on the results of a thorough study of the legal framework and scientific opinions, the opinion on the essence of wages is expressed and substantiated as a monetary (or in another form) expression of employee remuneration provided by the employer for work performed in the production or management process. In our opinion, it is properly organized accounting of payments to employees will contribute to the implementation of wages and other payments of their basic functions (reproductive, incentive, optimization, regulatory, social).

Approaches to finding ways to improve wage accounting should be based on its essence as a complex multilevel system, take into account the practice and problems of accounting, take into account the need to reduce the tax burden on the payroll and the amount of «shadow» wages.

\section{1. Ветуп}

Заробітна плата виступає об'єктом багатьох наукових досліджень і являється складною категорією, адже є елементом соціально-трудових відносин держави, роботодавця і найманого працівника. В умовах сьогодення, заробітна плата виступає основним інструментом реалізації соціального захисту працівників. Від іiі раціональної організації залежить ефективність праці та результати праці, а отже, розвиток країни в цілому. Небезпідставно науковці стверджують, на сьогодні, заробітна плата фактично перетворилась на один із варіантів соціальної допомоги, який мало залежить від результатів праці.

Облік та оподаткування виплат працівникам $є$ предметом наукових досліджень багатьох вчених і практиків, зокрема: Воськало Н.M., 
Воськало В.І., Глухової С.В., Головачової А.О., Костишеної Т.А., Лисак В.Ю., Машевської А.А., Мельник Т.Г., Овсюк Н.В., Островерхої Р.Е., Селіванова Н.М., Томчук О.Ф. та інших. Віддаючи належне науковим доробкам вчених, слід відзначити про відсутність єдиного обгрунтованого підходу до сутності взаємопов'язаних визначень «оплата праці», «заробітна плата», «поточні виплати працівникам». У відповідності із цим існує велика кількість авторських та законодавчо встановлених визначень, що негативно впливає на систему обліку розрахунків за виплатами працівникам.

Метою наукової публікації є дослідження економічної сутності заробітної плати, розкриття порядку iï оподаткування та обгрунтування шляхів удосконалення обліку розрахунків за поточними виплатами працівникам.

\section{2. Сутність заробітної плати}

Сутність поняття «заробітна плата» складне і багатосторонне, досить часто його ототожнюють зі змістом «оплата праці» та «виплати працівникам». Тому розглядати природу заробітної плати потрібно 3 різних позицій та розмежуванні основних теоретичних і правових основ трудового, бухгалтерського та податкового законодавства.

Відповідно до норм трудового законодавства України, заробітна плата визначається як винагорода, обчислена, як правило, у грошовому виразі, яку за трудовим договором роботодавець виплачує працівникові за виконану ним роботу [8; 22]. При цьому розмір заробітної плати залежить від складності та умов виконуваної роботи, професійно-ділових якостей працівника, результатів його праці, господарської діяльності підприємства тощо.

Законом України «Про оплату праці» [22] визначено правову основу структури заробітної плати, згідно з якою до ії складу входять основна, додаткова заробітна плата та інші заохочувальні і компенсаційні виплати. В інструкції зі статистики заробітної плати надано детальний перелік найменувань виплат, які входять до фонду оплати праці, й виплат, які не належать до нього [6].

У Податковому кодексі України визначено, що заробітна плата - це основна та додаткова заробітна плата, інші заохочувальні та компенсаційні виплати, які виплачуються (надаються) платнику податку у 
зв’язку з відносинами трудового найму згідно із законом. Окреслено, що заробітна плата нарахована (виплачена) платнику податку відповідно до умов трудового договору (контракту) включається до загального місячного (річного) оподатковуваного доходу платника податку і $є$ базою оподаткування податком 3 доходів фізичних осіб (ПДФО) та військовим збором (В3) [16]. Дискусійним можна визначити підхід до заохочувальних та компенсаційних виплат. Відповідно до Інструкції зі статистики [6] до них відносяться: одноразові заохочення, не пов'язані з конкретними результатами праці (наприклад, до ювілейних та пам'ятних дат); виплати соціального характеру у грошовій і натуральній формі. Такі нечіткі формулювання можуть впливати на допущення помилок при оподаткуванні виплат працівникам.

Облікові основи заробітної плати визначає Положення (стандарт) бухгалтерського обліку (ПСБО) 26 «Виплати працівникам» [18]. При цьому визначення заробітної плати відсутне, приводиться характеристика поточних виплат працівнику - це виплати працівнику (окрім виплат при звільненні та виплат інструментами власного капіталу підприємства), які підлягають сплаті в повному обсязі протягом дванадцяти місяців по закінченні місяця, у якому працівник виконував відповідну роботу. До поточних виплат працівникам включають: заробітну плату за окладами та тарифами, інші нарахування з оплати праці; виплати за невідпрацьований час (щорічні відпустки та інший оплачуваний невідпрацьований час); премії та інші заохочувальні виплати, що підлягають сплаті протягом дванадцяти місяців по закінченні періоду, у якому працівники виконують відповідну роботу, тощо.

Тобто, у нормативних документах використовуються різні підходи, відсутнє чітке визначення досліджуваної категорії. У зв'язку із цим в наукових дослідженнях, залежно від поглядів науковців, спостерігається велика кількість трактувань сутності заробітної плати (табл. 1).

Є підстава погодитись 3 твердженням Овсюк Н.В. [13, с. 28] про те, що 3 позиції правового аспекту термін «оплата праці» ширший i його цільове призначення спрямоване на організацію оплати праці, регламентацію їі окремих елементів та всієї системи правових засобів у цій сфері, тоді як поняття «заробітна плата» спрямоване на право окремого працівника отримувати грошову винагороду, тобто заробітна плата є елементом оплати праці. 
Таблиця 1

Дослідження поняття «заробітна плата» у літературних джерелах

\begin{tabular}{|c|c|c|}
\hline Підхід & Сутність & Представники \\
\hline Вартісний & $\begin{array}{l}\text { Заробітна плата розглядається з позиції ціни } \\
\text { праці, яку отримує працівник }\end{array}$ & $\begin{array}{l}\text { Брезицька К.Ф, } \\
\text { Бутинець Ф.Ф., } \\
\text { Дубовська О.В }\end{array}$ \\
\hline Ринковий & $\begin{array}{l}\text { Заробітна плата - це елемент ринку праці, } \\
\text { що є ціною, за якою найменший працівник } \\
\text { продає послуги робочої сили. }\end{array}$ & $\begin{array}{c}\text { Колот А.М., } \\
\text { Жидовська Н.М }\end{array}$ \\
\hline Мотиваційний & $\begin{array}{l}\text { Заробітна плата - це елемент витрат } \\
\text { виробництва, і водночас головний чинник } \\
\text { забезпечення матеріальної зацікавленості } \\
\text { працівників у досягненні високих кінцевих } \\
\text { результатів праці }\end{array}$ & $\begin{array}{c}\text { Калина А.В., } \\
\text { Мочерний С.В., } \\
\text { Пашута Н.І., } \\
\text { Швець Л.П., } \\
\text { Яременко Л.М. }\end{array}$ \\
\hline Юридичний & $\begin{array}{l}\text { Заробітна плата - винагорода, обчислена } \\
\text { як правило, у грошовому виразі, яку за } \\
\text { трудовим договором власник або уповнова- } \\
\text { жений ним орган виплачує працівникові за } \\
\text { виконану ним роботу }\end{array}$ & $\begin{array}{l}\text { Васильчак С.В., } \\
\text { Золотогоров В.Г., } \\
\text { Петрова І.Л., } \\
\text { Усач В.Б }\end{array}$ \\
\hline
\end{tabular}

Джерело: [2, с. 699]

3 погляду Мельник Т.Г. [11, с. 122], оплата праці, як обліково-аналітична категорія, характеризує трудовий дохід працівника, який формується під впливом кількості та якості затраченої корисної праці і виплачується працедавцем у вигляді заробітної плати в грошовій або натуральній формі. Така думка автора підкреслює розмежовування взаємопов'язаних, але не ідентичних понять «оплата праці» і «заробітна плата».

При порівнянні співвідношення оплати праці і заробітної плати, вдалою $є$ думка Головачової А.О. [3, с. 86], яка приводить порівняння 3 категоріями можливості та дійсності. На думку автора, можливість характеризує ступінь, тенденцію розвитку такого явища, яким є оплата праці, це шанс, який можна отримати за певних умов. Дійсність - це результат реалізації можливості, це вже об'єктивно наявна, зароблена працівником сума (заробітна плата) як винагорода в грошовому виразі. Для перетворення правової можливості (оплати праці) в правову дійсність (заробітну плату) потрібен юридичний факт, наявність якого і впливає на коло та зміст прав і обов'язків сторін трудового договору. 
Саме праця та її результат як юридичний факт трансформують правову можливість у правову реальність, оплату праці в заробітну плату.

На думку науковців [9, с. 69], різноманітність визначень заробітної плати обумовлюється наступними причинами: невизначеністю товару, що купується і продається на ринку праці; перехідним станом оплати праці в трансформаційній економіці, де існують нові елементи, характерні для ринкової системи оплати праці, та старі, що перейшли від командно-адміністративної системи; різницею методологічних підходів до аналізу системи відносин, що виражені категорією оплати праці; різним рівнем наукової абстракції до визначення системи економічних відносин, що виражені даною категорією, викликаними тими чи іншими дослідницькими цілями.

Зважаючи на багатоаспектність представленої дефініції вчені вважають за доцільне розглядати іiї з декількох позицій, а саме: 3 позиції економічної теорії, з позиції ринкової економіки, з позиції економіки праці, з позиції найманого працівника та 3 позиції підприємця. Так, 3 позиції економічної теорії, заробітна плата - це економічна категорія, що відображає відносини між роботодавцем і найманим працівником з приводу розподілу новоствореної вартості. В умовах ринкової економіки заробітна плата - це елемент ринку праці, що складається в результаті взаємодії попиту на працю та їі пропозиції й виражає ринкову вартість використання найманої праці. 3 позицій економіки праці, заробітна плата - це винагорода або заробіток, обчислений у грошовому виразі, який за трудовим договором роботодавець сплачує працівникові за роботу, яку виконано або має бути виконано. 3 позиції найманого працівника, заробітна плата - це основна частина його трудового доходу, який він отримує в результаті реалізації здатності до праці і який має забезпечити об'єктивно необхідне відтворення робочої сили. 3 позицій підприємця, заробітна плата - це елемент витрат виробництва і водночас головний чинник забезпечення матеріальної зацікавленості працівників у досягненні високих кінцевих результатів праці [10, с. 265].

Вище викладений матеріал дає можливість охарактеризувати взаємозв'язок вище розглянутих категорій (рис. 1).

Отже, всі дефініції взаємопов'язані, доповнюють одна одну і характеризують певні взаємовідносини зацікавлених сторін та зміст розрахунків між ними. 


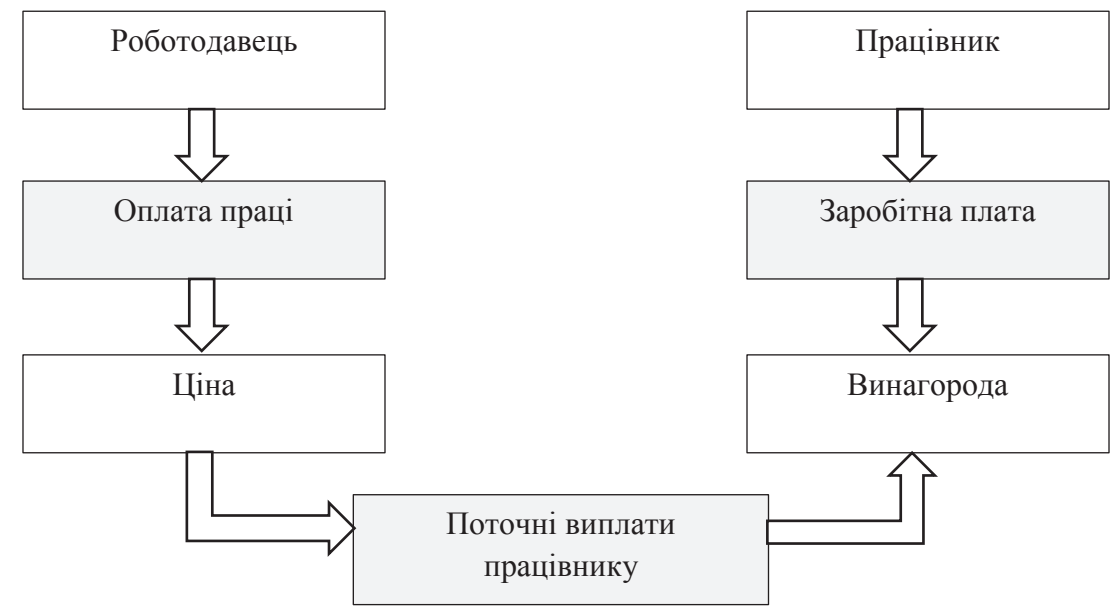

\section{Рис. 1. Взаємозв'язок визначень «оплата праці»,} «заробітна плата», «поточні виплати працівникам»

Джерело: сформовано автором

Враховуючи нормативно-правове та теоретичне підгрунтя сутності заробітної плати, вважаємо, що найбільш вдалим визначенням заробітної плати $є$ наступне: заробітна плата - це грошове (чи в іншій формі) вираження винагороди працівника, яка надається роботодавцем за виконану ним роботу у процесі виробництва чи управління. На нашу думку, саме правильно організований облік розрахунків за виплатами працівникам сприятиме виконанню заробітною платою та іншими виплатами їх основних функцій (відтворювальної, стимулюючої, оптимізаційної, регулювальної, соціальної).

\section{3. Облікове забезпечення розрахунків за виплатами працівникам}

Облік заробітної плати потребує своєчасних оперативних і точних даних, адже вона пов'язана не лише з розрахунками із працівниками, а й - з бюджетом та фондами страхування. Тому, правильно організований облік заробітної плати забезпечує об'єктивність відображення інформації та своєчасність формування усіх форм звітності (фінансової, статистичної, податкової, спеціальної) [17]. Це в свою чергу забез- 
печує оцінку зарплатних показників, можливість порівняння номінальної та реальної заробітної плати, аналіз податкових надходжень до бюджетів та перспективи податкової політики.

3 метою підтвердження актуальності дослідження розглянемо динаміку середньомісячної заробітної плати та основних соціальних гарантій за останні роки (табл. 2).

Таблиця 2

Основні дані по заробітній платі за 2015-2020 рр., грн.

\begin{tabular}{|l|c|c|c|c|c|c|}
\hline \multicolumn{1}{|c|}{ Показники } & 2015 p. & 2016 p. & 2017 p. & 2018 p. & 2019 p. & 2020 p. \\
\hline $\begin{array}{l}\text { Середньомісячна } \\
\text { заробітна плата } \\
\text { у розрахунку на } \\
\text { одного штатного } \\
\text { працівника }\end{array}$ & 4195 & 5183 & 7104 & 8865 & 10497 & $\begin{array}{c}11006 \\
\text { (січень- } \\
\text { березень) }\end{array}$ \\
\hline $\begin{array}{l}\text { Мінімальна заро- } \\
\text { бітна плата }\end{array}$ & 1218 & 1378 & 3200 & 3723 & 4173 & 4723 \\
\hline $\begin{array}{l}\text { Прожитковий } \\
\text { мінімум (для пра- } \\
\text { цездатних осіб) }\end{array}$ & 128 & 1378 & 1600 & 1762 & 1921 & 2102 \\
\hline
\end{tabular}

Джерело: сформовано автором на основі [12; 26]

Аналізуючи дані таблиці 2, спостерігається зростання із року в рік розміру мінімальної заробітної плати, рівня середньомісячної заробітної плати та прожиткового мінімуму. Однак ці показники $\epsilon$ досить низькими і підтверджують зменшення реального рівня заробітної плати. Все це свідчить про необхідність активізації державної соціальної політики, досягнення соціально прийнятного життєвого рівня та врегулювання його гарантій відповідно до соціальних стандартів і нормативів, суттєвих змін в організації й стимулюванні ефективності праці, оптимізації диференціації доходів працюючих та їх оподаткування, що є обов'язковою передумовою сталого соціально-економічного розвитку. Тому важливими питаннями, на які необхідно звернути увагу в умовах сьогодення - це облікове забезпечення розрахунків за поточними виплатами працівникам та їх оподаткування, як інформаційної основи для будь-якого аналізу. 
Що ж ми розуміємо під поняттям облікове забезпечення? Облік генерує відомості про факти господарської діяльності підприємств. Слово забезпечення розуміється як процес підготовки та формування облікової інформації для цілей управління. Таким чином, облікове забезпечення розрахунків за поточними виплатами працівникам - це процес формування доречної та достовірної інформації в різних підсистемах бухгалтерського обліку про розрахунки $з$ працівниками за виконану роботу та інші виплати прирівняні до заробітної плати.

Облік розрахунків з працівниками по заробітній платі можна представити поетапністю виконання наступних процедур:

- нарахування заробітної плати: згідно штатного розпису, трудових договорів, табеля обліку робочого часу при погодинній формі оплати праці (з урахуванням державних гарантій при роботі у вихідні та святкові дні, в ненормований час, в нічний час і інших) тощо; нарахування премій, надбавок, компенсацій, пільг, понаднормових, відпускних; розрахунок щомісячної індексації заробітної плати; розрахунок при звільненні та скороченні; облік виплат за рахунок фондів соціального страхування (лікарняні, путівка тощо); медичного страхування та страхування життя; інші нарахування, передбачені законодавством;

- нарахування єдиного соціального внеску загальнообов'язкове державне соціальне страхування на фонд оплати праці працівників, які працюють на умовах трудового та цивільно-правового договорів;

- розрахунок податків і зборів, що утримуються із заробітної плати: податку з доходів фізичних осіб та військового збору;

- утримання за виконавчими листами: стягнення аліментів на утримання неповнолітніх дітей або непрацездатних батьків;

- інші утримання: за заявами працівників профспілкових внесків, вартість виданих у рахунок оплати праці продукції, наданих послуг; відшкодування матеріального збитку; неповернуті підзвітні суми тощо.

Таким чином, з моменту нарахування заробітної плати та прирівняних до неї виплат у роботодавця (податкового агента) виникають зобов'язання за розрахунками із страхування та податками і платежами (рис. 2):

- за єдиним внеском на загальнообов'язкове державне соціальне страхування (ССВ) - нараховується на суму виплат працівника, але сплачується за рахунок коштів роботодавця; 


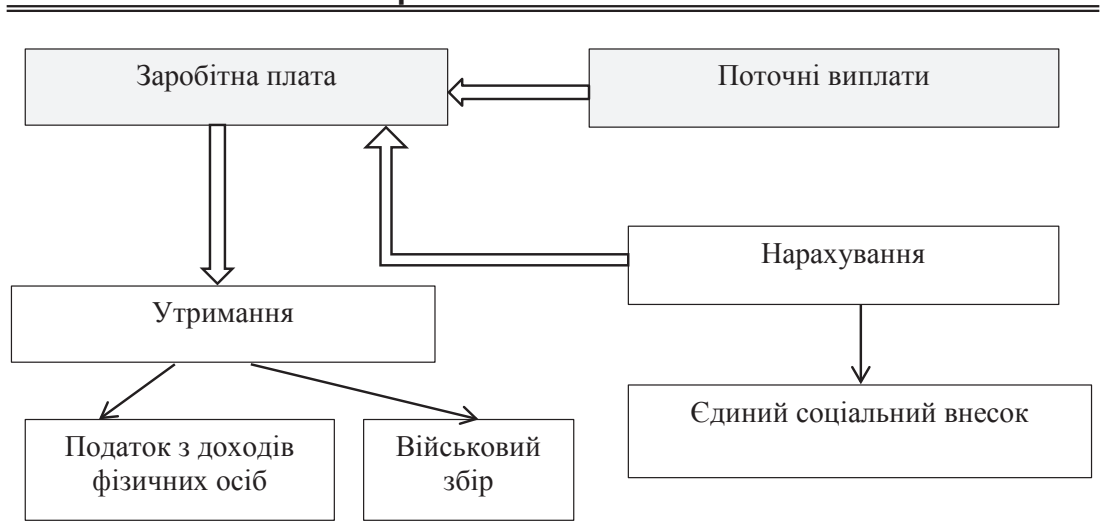

\section{Рис. 2. Оподаткування заробітної плати працівників}

Джерело: сформовано автором

- за ПДФО та В3 - утримуються із суми виплат працівника та сплачуються роботодавцем за рахунок доходу найманого працівника.

Відповідно до чинного законодавства України [21], єдиний внесок на загальнообов'язкове державне соціальне страхування (єдиний внесок) - це консолідований страховий внесок, збір якого здійснюється до системи загальнообов' язкового державного соціального страхування в обов'язковому порядку та на регулярній основі з метою забезпечення захисту у випадках, передбачених законодавством, прав застрахованих осіб на отримання страхових виплат (послуг) за діючими видами загальнообов'язкового державного соціального страхування.

Таким чином, єдиний внесок включає в себе повний соціальний пакет, який складається 3 пенсійного страхування (виплата пенсіі), страхування на випадок тимчасової втрати працездатності (оплата лікарняних, догляд за дитиною тощо), страхування, пов'язане з виникненням нещасних випадків на виробництві (компенсація повної або часткової втрати працездатності).

За чинним законодавством України [21], утримання єдиного внеску нараховуються: на суму нарахованої кожній застрахованій особі заробітної плати за видами виплат, які включають основну та додаткову заробітну плату, інші заохочувальні та компенсаційні виплати, у тому числі в натуральній формі, що визначаються відповідно до Закону 
України «Про оплату праці», та суму винагороди фізичним особам за виконання робіт (надання послуг) за цивільно-правовими договорами; на суму грошового забезпечення кожної застрахованої особи, оплати перших п’яти днів тимчасової непрацездатності, що здійснюється за рахунок коштів роботодавця, та допомоги по тимчасовій непрацездатності, допомоги у зв'язку з вагітністю та пологами; допомоги, надбавки або компенсації відповідно до законодавства; для фізичних осіб підприємців - на суму доходу (прибутку), отриманого від їх діяльності, що підлягає обкладенню податком на доходи фізичних осіб; для фізичних осіб підприємців, які обрали спрощену систему оподаткування на суми, що визначаються такими платниками самостійно для себе, але не більше максимальної величини бази нарахування єдиного внеску. При цьому сума єдиного внеску не може бути меншою за розмір мінімального страхового внеску.

Єдиний внесок обчислюється виключно у національній валюті, у тому числі з виплат (доходу), що здійснюються в натуральній формі.

При визначенні бази нарахування єдиного внеску, враховується:

1) максимальна величина бази нарахування єдиного внеску - здійснюється на суму, яка визначена як 15 розмірів мінімальних заробітних плат;

2) мінімальна межа бази нарахування єдиного внеску - визначається 3 врахуванням розміру мінімальної заробітної плати, встановленої на 1 січня поточного року. Проте, якщо база нарахування єдиного внеску не перевищує розміру мінімальної заробітної плати, встановленої законом на місяць, за який отримано дохід, сума єдиного внеску розраховується як добуток розміру мінімальної заробітної плати, встановленої законом на місяць, за який отримано дохід (прибуток), та ставки єдиного внеску. При нарахуванні заробітної плати (доходів) фізичним особам з джерел не за основним місцем роботи ставка єдиного внеску застосовується до визначеної бази нарахування незалежно від ії розміру [21].

Законодавчо визначені ставки єдиного внеску за останні роки $є$ незмінними, про що свідчать дані таблиці 3.

Нарахування і сплата єдиного внеску відбувається одночасно 3 виплатою заробітної плати працівнику, оскільки це прямий обов'язок роботодавця.

Загальні суми надходжень коштів з єдиного внеску за період 2016-2019 років подані в таблиці 4. 


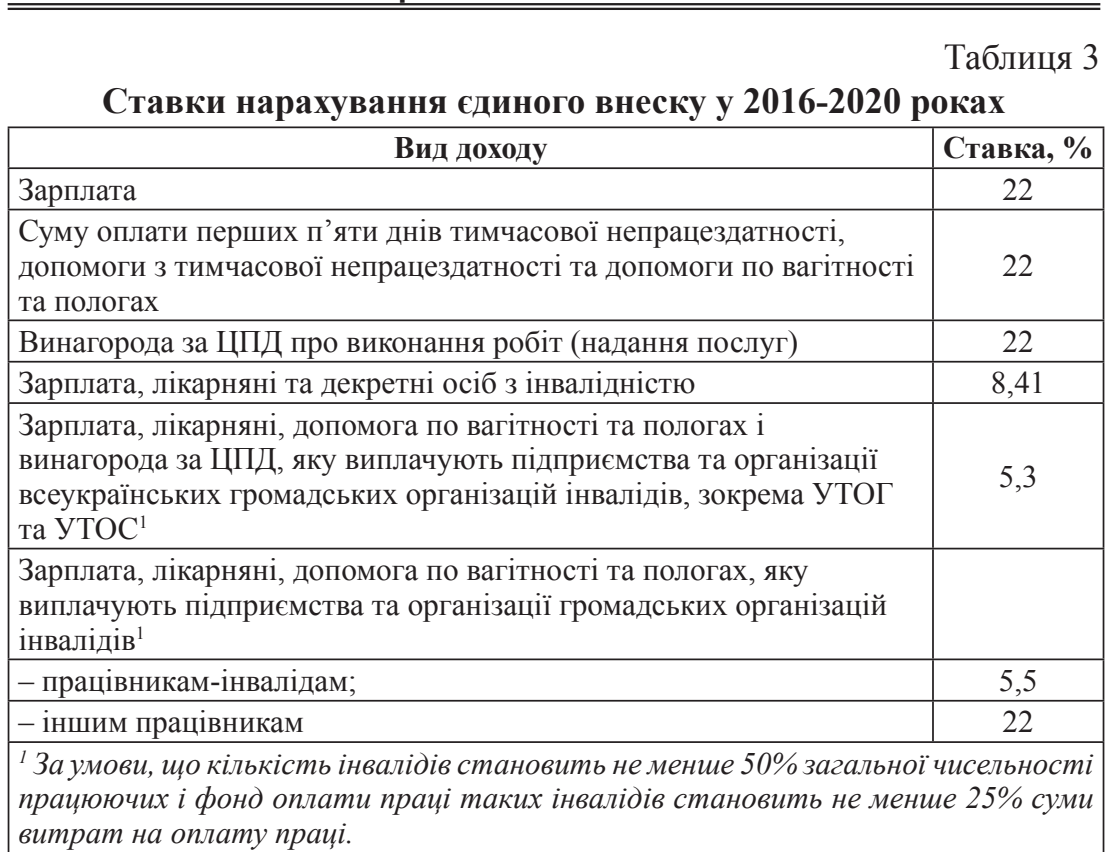

Джерело: сформовано за [21]

Дані наведені з 2016 року, оскільки було відмінено утримання із сум нарахованої заробітної плати. Як спостерігається із даних таблиці 4, сума надходжень до фондів соціального страхування i Пенсійного фонду з року в рік зростає. Сума отриманих внесків у 2019 році зросла порівняно з 2016 роком у 2,1 рази. Це пов'язано із зростанням кількості платників єдиного внеску (юридичних та фізичних осіб) на 805877 осіб. Загальна сума доходу працівників (зарплата, грошове забезпечення, інші види доходу) у 2016 році становила 627902 010,07 тис. грн., що на 79\% менше ніж за 2019 рік. Разом з тим у 2019 році, сума на яку нараховувався єдиний соціальний внесок 1238293 234,64 тис. грн., тобто більше 50 млрд. грн. доходу працюючих не обкладається єдиним соціальним внеском. Надходження до фондів соціального страхування від єдиного внеску протягом 2019 року зросла до 273480 015,92 тис. грн., що на 141653251,66 тис. грн. більше ніж в 2016 році. 
Olena Podolianchuk

\begin{tabular}{|c|c|c|c|c|c|c|c|c|c|c|}
\hline \multirow{5}{*}{ 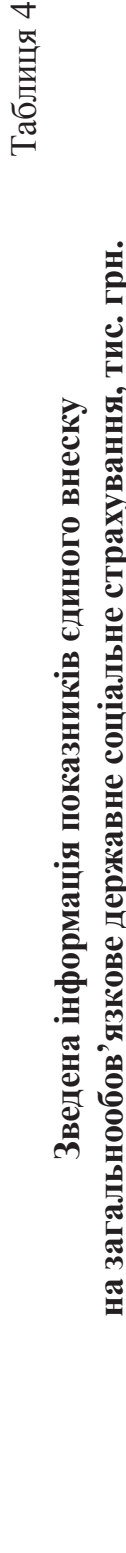 } & $\stackrel{\dot{0}}{\hat{\sigma}}$ & 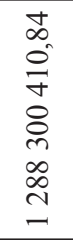 & 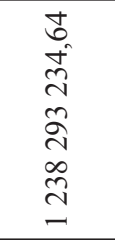 & 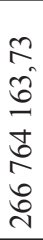 & 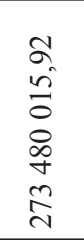 & & 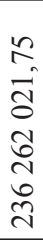 & 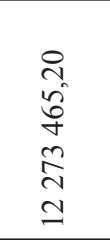 & 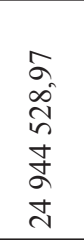 & 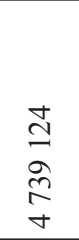 \\
\hline & $\frac{\dot{\infty}}{\vec{\sigma}}$ & $\begin{array}{l}\mathfrak{n} \\
\hat{N} \\
\alpha \\
n \\
\infty \\
\infty \\
\hat{\sigma} \\
0 \\
-\end{array}$ & 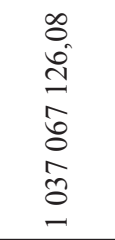 & 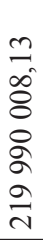 & 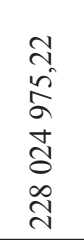 & & 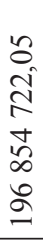 & $\begin{array}{l}\vec{\nabla} \\
\hat{\Omega} \\
0 \\
\vec{\infty} \\
\stackrel{n}{=} \\
=\end{array}$ & 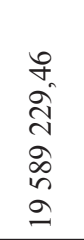 & 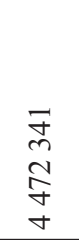 \\
\hline & $\frac{\dot{2}}{\tilde{D}}$ & $\begin{array}{l}n \\
m \\
m \\
i n \\
\pm \\
I \\
\dot{b} \\
\infty\end{array}$ & 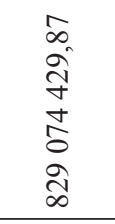 & 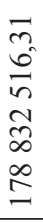 & 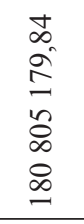 & & 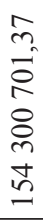 & $\begin{array}{l}\text { I } \\
\text { N } \\
\text { N } \\
\infty \\
\infty \\
a\end{array}$ & 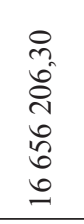 & $\begin{array}{l}2 \\
2 \\
\infty \\
\infty \\
\nabla \\
\nabla\end{array}$ \\
\hline & $\frac{\dot{e}}{0}$ & 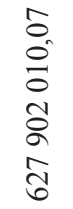 & 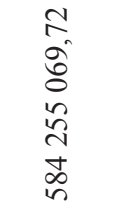 & 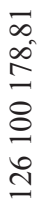 & 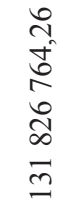 & & 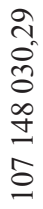 & $\begin{array}{l}\hat{\sigma} \\
\vec{\infty} \\
\infty \\
\infty \\
\infty \\
\infty\end{array}$ & 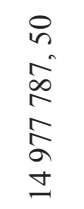 & $\begin{array}{l}\text { J } \\
\text { m } \\
\text { } \\
m\end{array}$ \\
\hline & 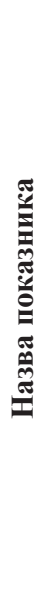 & 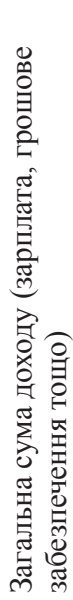 & 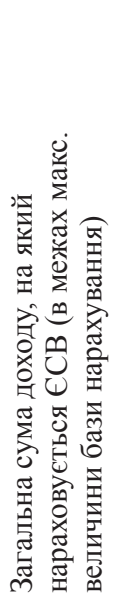 & 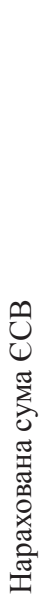 & 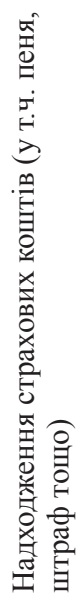 & 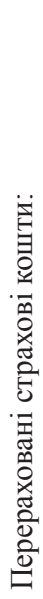 & 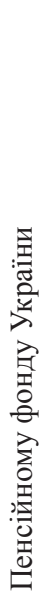 & 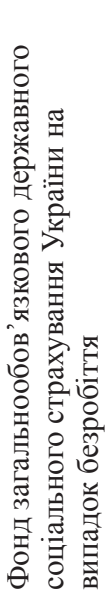 & 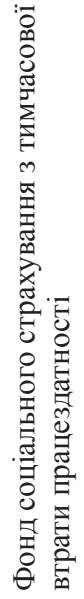 & 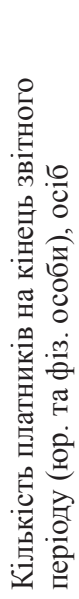 \\
\hline
\end{tabular}


Не зважаючи на те, що кількість боржників зменшується, сума недоїмки із сплати єдиного соціального внеску зростає та на кінець 2019 року становила 16880 116,89 тис. грн. У середньому на одного боржника припадає 22,56 тис. грн. недоїмки. Крім цієї недоїмки, сума боргу із штрафів та пені складає 1622 743,54 тис. грн., що також зростає з року в рік. Ріст податкового навантаження дав очікувані результати у вигляді незначного наповнення Пенсійного фонду та фондів соціального страхування.

Як вже зазначалося, роботодавець із заробітної плати здійснює утримання двох платежів: ПДФО та військового збору.

У Податковому кодексі відсутнє визначення ПДФО.

Відзначимо: ПДФО - це один із загальнодержавних податків, що стягується 3 доходів фізичних осіб (громадян - резидентів і нерезидентів), які отримують доходи 3 джерел їх походження в Україні та відноситься до групи прямих. Він є одним із важливих бюджетоутворюючих податків як держави так і місцевих бюджетів (табл. 5).

Таблиця 5

\section{Динаміка надходження ПДФО}

до державного та місцевого бюджетів, млн. грн.

\begin{tabular}{|c|c|c|c|}
\hline \multirow{2}{*}{ Рік } & \multicolumn{3}{|c|}{ Надходження ПДФО } \\
\cline { 2 - 4 } & $\begin{array}{c}\text { Загальнодержавний } \\
\text { бюджет }\end{array}$ & Місцеві бюджети & Зведений бюджет \\
\hline 2015 & 45062,0 & 54921 & 99983,2 \\
\hline 2016 & 59810,5 & 78970,7 & 138781,2 \\
\hline 2017 & 75033,4 & 110652,7 & 185686,1 \\
\hline 2018 & 91741,8 & 138158,8 & 229900,6 \\
\hline 2019 & 109954,0 & 165504,5 & 275458,5 \\
\hline
\end{tabular}

Джерело: сформовано за [4]

За даними таблиці 5 спостерігається щорічне зростання сум надходження ПДФО до бюджету. У 2019 році до зведеного бюджету України надійшло 275 458,5 млн. грн. ПДФО, що становить 15\% загального обсягу зведеного бюджету України. Порівняно з 2015 роком надходження ПДФО зросло майже на третину (на 74\%). Із загального обсягу ПДФО більша половина надійшла до місцевого бюджету. 
У цьому і проявляється специфіка ПДФО як загальнодержавного податку. На важливість ПДФО, як одного із суттєвих бюджетоутворюючих податків вказує той факт, що з кожним роком зростає обсяг цього податку та його частка у зведеному бюджеті України (рис. 3).

Відповідно до Податкового кодексу, заробітна плата є об'єктом оподаткування ПДФО і його ставка складає $18 \%$ бази оподаткування (щодо доходів, нарахованих у тому числі, але не виключно у формі: заробітної плати, інших заохочувальних та компенсаційних виплат або інших виплат і винагород, які нараховуються платнику у зв'язку з трудовими відносинами та за цивільно-правовими договорами).

При цьому, відповідно до норм ПКУ деякі виплати, які не включаються до фонду оплати праці згідно з Інструкцією № 5, для цілей обкладення ПДФО прирівнюються до заробітної плати (наприклад, лікарняні, декретні).

Позитивним кроком в методиці оподаткування ПДФО є введення податкової соціальної пільги (ПСП). База оподаткування ПДФО визна-

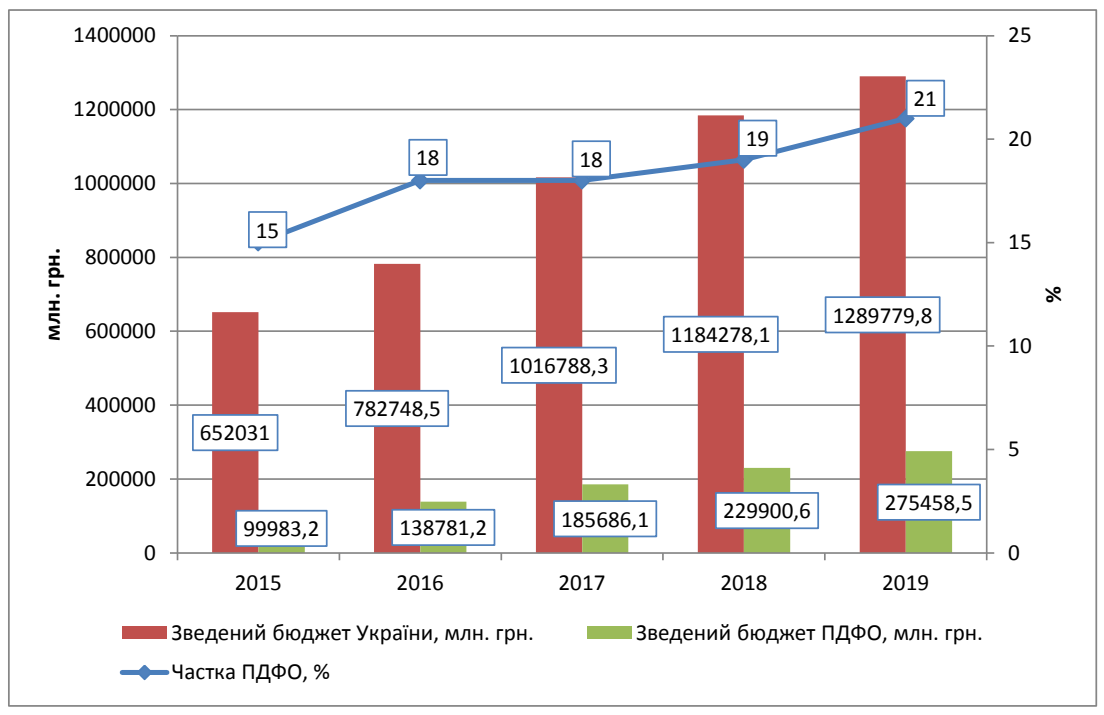

Рис. 3. Частка ПДФО у зведеному бюджеті

Джерело: сформовано за [4] 
чається з урахуванням ПСП, якщо працівник має право на неї. ПСП застосовується до нарахованого платнику податку місячного доходу тільки у вигляді заробітної плати тільки за одним місцем його нарахування (виплати). ПСП може загальна або підвищена. Кожен працівник має право на застосування до свого доходу загальної податкової соціальної пільги, якщо розмір його місячної заробітної плати не перевищує граничного розміру доходу, що дорівнює місячному прожитковому мінімуму, діючому для працездатної особи на 1 січня звітного податкового року, помноженому на 1,4 та округленого до найближчих 10 гривень [16].

Загальна податкова соціальна пільга дорівнює 50\% розміру прожиткового мінімуму для працездатної особи станом на 1 січня. Окремі фізичні особи, перелік яких визначено п.п. 169.1 Податкового кодексу України, мають право скористатися підвищеними соціальними пільгами, що дорівнюють 100\%, 150\% або 200\% від загальної ПСП (табл. 6).

Варто відзначити про те, що база оподаткування ПДФО може бути зменшена на суму страхових внесків до Накопичувального фонду, а у випадках, передбачених законом, - обов'язкових страхових внесків до недержавного пенсійного фонду, які відповідно до закону сплачуються за рахунок заробітної плати працівника.

Неможна оминути методику розрахунку ПДФО із заробітної плати у натуральній формі, яка відповідно до законодавства може виплачуватися у розмірі, що не перевищує $30 \%$ від нарахованої за місяць. Натуральна оплата нараховується у тих галузях або за тими професіями, де така виплата, еквівалентна за вартістю оплаті праці у грошовому виразі, $\epsilon$ звичайною або бажаною для працівників, крім товарів, перелік яких встановлюється Кабінетом Міністрів України (ч. 3 ст. 23 Закону № 108).

Оподаткування заробітної плати у натуральній формі здійснюється 3 урахуванням «натурального» коефіцієнта, який визначається за формулою:

$$
\text { К }=100 \div(100-\text { Сп })
$$

де К - натуральний коефіцієнт;

Сп - ставка податку, встановлена для таких доходів на момент їх нарахування.

Якщо здійснити розрахунки, то натуральний коефіцієнт дорівнює 1,21951. Таким чином база оподаткування ПДФО буде збільшуватися на 
Таблиця 6

Розмір податкових соціальних пільг

\begin{tabular}{|c|c|c|c|c|c|c|}
\hline \multirow[b]{2}{*}{ Рік } & \multirow{2}{*}{$\begin{array}{c}\text { Граничний } \\
\text { розмір } \\
\text { доходу, } \\
\text { який дає } \\
\text { право на } \\
\text { отримання } \\
\text { ПСП, грн. }\end{array}$} & \multirow[b]{2}{*}{$\begin{array}{c}\text { Прожитковий } \\
\text { мінімум } \\
\text { (ПМ), грн. }\end{array}$} & \multirow{2}{*}{$\begin{array}{c}\text { Розмір } \\
\text { звичайної } \\
\text { пільги, } \\
\text { 50\% ПМ }\end{array}$} & \multicolumn{3}{|c|}{$\begin{array}{c}\text { Сума підвищеної ПСП, } \\
\text { грн. від звичайної }\end{array}$} \\
\hline & & & & $100 \%$ & $150 \%$ & $200 \%$ \\
\hline 2015 & 1710 & 1218 & 609,5 & 609,5 & 913,5 & 1218 \\
\hline 2016 & 1930 & 1378 & 689 & 689 & 1033,5 & 1378 \\
\hline 2017 & 2240 & 1600 & 800 & 800 & 1200 & 1600 \\
\hline 2018 & 2470 & 1762 & 881 & 881 & 1321,5 & 1762 \\
\hline 2019 & 2690 & 1921 & 960,5 & 960,5 & 1440,75 & 1921 \\
\hline 2020 & 2940 & 2102 & 1051 & 1051 & 1576,5 & 2102 \\
\hline
\end{tabular}

Джерело: розраховано та узагальнено автором на основі [16; 23]

розмір натурального коефіцієнта. Держава здійснила такі заходи з метою недопущення зловживань при визначені цін на продукцію (не нижче собівартості), яка передається робітникам як натуральна оплата праці.

3 серпня 2014 року встановлено утримання військового збору за ставкою 1,5\% від об'єкта оподаткування. Об'єктом оподаткування військовим збором є доходи у формі заробітної плати, інших заохочувальних та компенсаційних виплат або інших виплат і винагород, які нараховуються (виплачуються, надаються) платнику у зв'язку з трудовими відносинами та за цивільно-правовими договорами.

Динаміка надходжень військового збору до бюджету представлена на рис. 4.

3 наведеного рис. 4 спостерігається, що станом на кінець 2019 року до бюджету надійшли 22,4 млрд. грн. Ця сума надходжень майже у 10 раз перевищує надходження у 2014 році, а також є більшою у порівняні 3 попередніми роками. Хоча військовий збір забезпечує надходження значної частини коштів на розвиток армії і ставка $є$ доволі низькою, вважаємо, що фізичні особи зробили за шість років достатній внесок для Збройних сил України. Держава зобов'язана звільнити працездатне населення та інших платників збору від податкового навантаження, адже заробітна плата для багатьох являється єдиним джерелом доходу. 
Chapter «Economic sciences»

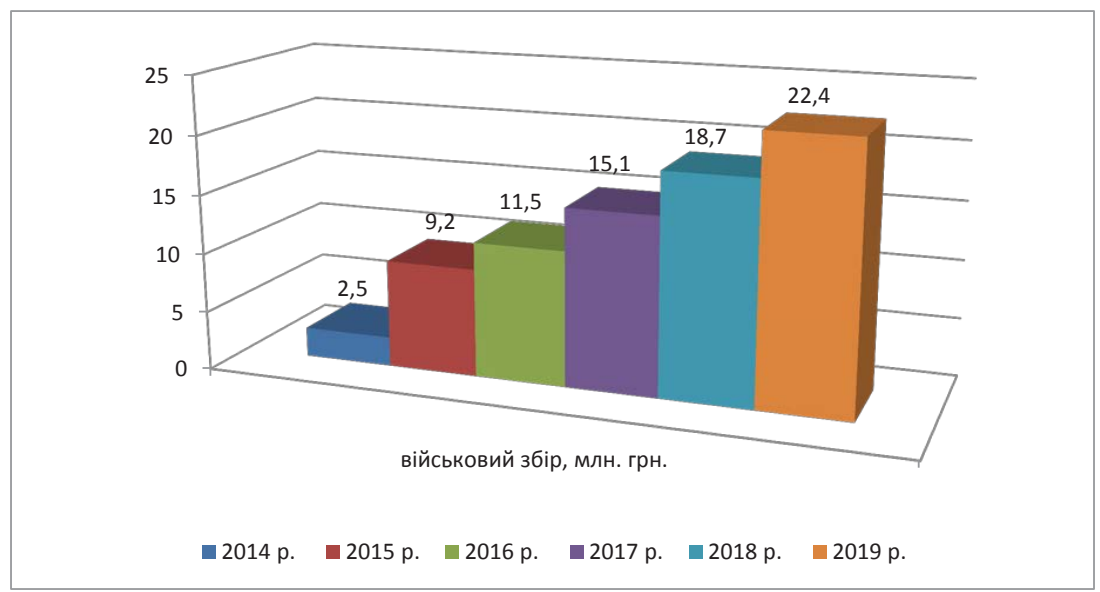

Рис. 4. Надходження військового збору до державного бюджету Джерело: сформовано за [5]

У випадку із заробітною платою базою оподаткування військовим збором є вся сума зарплати. Військовий збір утримується з повної суми нарахованої заробітної плати без вирахування податку на доходи фізичних осіб. Проте, не підлягають оподаткуванню військовим збором такі доходи, як суми допомоги з вагітності та пологів, винагород і страхових виплат, що отримуються платником податків з бюджетів та фондів загальнообов'язкового державного соціального страхування; грошові кошти або вартість майна (послуг), що надаються як допомога на лікування або медичне обслуговування платника податків; допомога на поховання в розмірах, визначених Податковим кодексом України (ПКУ); стипендії; основна сума зворотної фінансової допомоги; вартість путівок на відпочинок, оздоровлення й лікування; вартість дарунків, якщо вона не перевищує 50\% однієї мінімальної зарплати; сума (вартість) добродійної допомоги [16].

Не включається у загальний місячний або річний оподатковуваний дохід платника податків добродійна, зокрема гуманітарна, допомога, яка відповідає критеріям, визначеним ПКУ, тобто всі види добродійної та гуманітарної допомоги, не оподатковувані податком з доходів фізичних осіб, не повинні обкладатися військовим збором. 
ПДФО та військовий збір сплачується під час кожної виплати доходу, з якого він утримується.

Розрахунки за виплатами працівникам та розрахунки за податками і зборами відображаються у бухгалтерському обліку через систему рахунків методом подвійного запису. Облік цієї ділянки є однією з найважливіших та найскладніших сторін облікового процесу.

В бухгалтерському обліку розрахунки 3 працівниками по заробітній платі узагальнюються на рахунку 66 «Розрахунки за виплатами працівникам». Даний рахунок призначено для узагальнення інформації про розрахунки з персоналом, який належить як до облікового, так і до необлікового складу підприємства, - 3 оплати праці (за всіма видами заробітної плати, премій, допомог тощо), а також розрахунки за неодержану персоналом у встановлений термін суму з оплати праці (розрахунки з депонентами).

Аналітичний облік розрахунків ведеться за кожним працівником, видами виплат та утримань.

Відповідно до Плану рахунків, рахунок 66 «Розрахунки за виплатами працівникам» має три субрахунки [7]: 661 «Розрахунки за заробітною платою»; субрахунок 662 «Розрахунки з депонентами»; субрахунок 663 «Розрахунки за іншими виплатами».

За кредитом рахунка 66 «Розрахунки за виплатами працівникам» відображаються нарахована працівникам суб'єкта господарювання основна та додаткова заробітна плата, премії, допомога за тимчасовою непрацездатністю, інші нарахування, за дебетом - виплата заробітної плати, премій, допомоги тощо, а також суми утриманих податків, платежів за виконавчими документами, вартість одержаних матеріалів, продукції та товарів у рахунок заробітної плати й інші утримання із сум оплати праці персоналу [7].

Для обліку розрахунків за сумами нарахованого податку з доходів фізичних осіб призначено субрахунком 641 «Розрахунки за податками» аналітичний рахунок «ПДФО», а для обліку військового збору - субрахунок 642 «Розрахунки за обов'язковими платежами» аналітичний рахунок «Військовий збір». За кредитом рахунку 64 «Розрахунки за податками й платежами» відображаються нараховані платежі до бюджету, за дебетом - перерахування у бюджет [7]. 
Розрахунки щодо єдиного внеску відображаються за субрахунком 651 «За розрахунками із загальнообов’ язкового державного соціального страхування» рахунку 65 «Розрахунки за страхуванням» [7]. Структура рахунку ідентична рахунку 64.

В наукових публікаціях виокремлюється дискусія щодо доцільності використання рахунку 661 «Розрахунки за заробітною платою» під час виплати авансів працівникам [1, с. 242]. Науковці стверджують, що внаслідок такої операції утворюється дебіторська заборгованість підприємства, яка відображається в активі Балансу, та логічним було б iii відображати на рахунку 377 «Розрахунки із іншими дебіторами» до дати нарахування заробітної плати. Також враховуючи те, що більшість підприємств перейшло на виплату заробітної плати через банківські платіжні картки, субрахунок 662 «Розрахунки з депонентами» поступово втрачає свою актуальність. Дещо проблемним є використання субрахунку 663 «Розрахунки за іншими виплатами», що призначений для розрахунків за виплатами, що не належать до фонду оплати праці, зокрема допомоги по частковому безробіттю, допомоги по тимчасовій непрацездатності. Суть проблеми полягає у тому, що об'єктом оподаткування ПДФО та військового збору є сукупний місячний оподатковуваний дохід працівника, що може охоплювати виплати, що нараховані як на рахунку 661, так і на рахунку 663. Відображення в обліку кореспонденції рахунків із нарахування ПДФО та військового збору у такій ситуації приводить до дилеми стосовно того, який рахунок має кореспондувати за дебетом із кредитом рахунку 641.

Інші дослідники [14] пропонують здійснити групування заробітної плати за категоріями працівників і відкривати рахунки третього порядку: 6611 «Розрахунки за заробітною платою адміністративно-управлінського персоналу»; 6612 «Розрахунки за заробітною платою інженерно-технічних працівників структурних підрозділів», 6613 «Розрахунки за заробітною платою робітників». Склад кожного аналітичного рахунка дасть можливість деталізують у розрізі виплат: посадовий оклад, доплати (за видами) та надбавки (за видами). Такий підхід дасть змогу отримати інформацію для різних цілей шляхом запису інформації одночасно у кількох аналітичних рахунках.

Отже, як засвідчують наукові дослідження, реформування бухгалтерського обліку заробітної плати шляхом удосконалення чинної 
Таблиця 7

Варіанти моделі обліку розрахунків за виплатами працівникам

\begin{tabular}{|c|c|}
\hline Автори & Субрахунки \\
\hline $\begin{array}{l}\text { О. Покатаєва, } \\
\text { Г. Кошулинська }\end{array}$ & $\begin{array}{l}661 \text { «Розрахунки за заробітною платою»; } \\
6611 \text { «Розрахунки за нарахованими виплатами»; } \\
66111 \text { «Поточні виплати»; } \\
66112 \text { «Заробітна плата за окладами і тарифами»; } \\
66113 \text { «нші нарахування з оплати праці»; } \\
66114 \text { «Виплати за невідпрацьований час»; } \\
66115 \text { «Премії та інші заохочувальні виплати»; } \\
66116 \text { «Комісійні винагороди»; } \\
6612 \text { «Виплати при звільненні»; } \\
6613 \text { «Виплати після закінчення трудової діяльності»; } \\
6614 \text { «Розрахунки за виплатою відпускних». } \\
\end{array}$ \\
\hline $\begin{array}{l}\text { М. Корягін, } \\
\text { О. Попкова }\end{array}$ & $\begin{array}{l}661 \text { «Розрахунки з оплати праці»; } \\
6611 \text { «Основна заробітна плата»; } \\
6612 \text { «Додаткова заробітна плата»; } \\
6613 \text { «Премії та інші заохочувальні виплати»; } \\
6614 \text { «Компенсаційні виплати»; } \\
662 \text { «Розрахунки з депонентами»; } \\
663 \text { «Розрахунки за іншими виплатами». }\end{array}$ \\
\hline Л. Мельянкова & $\begin{array}{l}661 \text { «Розрахунки за заробітною платою»; } \\
662 \text { «Розрахунки з депонентами»; } \\
663 \text { «Розрахунки за іншими виплатами»; } \\
664 \text { «Розрахунки за виплатами заробітної плати в формі натуроплати»; } \\
665 \text { «Розрахунки з депонентами при натуральній формі оплати праці». }\end{array}$ \\
\hline $\begin{array}{l}\text { Т. Плахтій, } \\
\text { В. Калашник }\end{array}$ & $\begin{array}{l}661 \text { «Розрахунки за заробітною платою»; } \\
6611 \text { «Основна заробітна плата»; } \\
6612 \text { «Виплати при звільненні»; } \\
6613 \text { «Виплати після закінчення трудової діяльності»; } \\
6614 \text { «Розрахунки за виплатою відпускних»; } \\
662 \text { «Розрахунки з депонентами»; } \\
663 \text { «Розрахунки за іншими виплатами»; } \\
664 \text { «Розрахунки за виплатами заробітної плати в натуральній формі». }\end{array}$ \\
\hline Н.М. Старченко & $\begin{array}{l}661 \text { «Розрахунки з оплати праці»; } \\
6611 \text { «Поточні виплати»; } \\
6612 \text { «Виплати при звільненні»; } \\
6613 \text { «нші виплати працівникам»; } \\
662 \text { «Розрахунки з працівниками за товари продані в кредит»; } \\
663 \text { «Розрахунки з працівниками за безготівковими перерахуван- } \\
\text { нями на рахунки з вкладів у банках»; } \\
664 \text { «Розрахунки з працівниками за безготівковими перерахуван- } \\
\text { нями внесків за договорами добровільного страхування»; } \\
665 \text { «Розрахунки з членами профспілки за безготівковими перера- } \\
\text { хуваннями сум членських профспілкових внесків»; } \\
666 \text { «Розрахунки з працівниками за позиками банків»; } \\
667 \text { «озрахунки за виконавчими документами та інші утримання». }\end{array}$ \\
\hline
\end{tabular}

Джерело: [25, с. 96] 
моделі аналітичного обліку знаходить своє відображення в багатьох працях науковців (табл. 7).

Також в наукових публікаціях висловлюється думка щодо необхідності розширення аналітичних рахунків до субрахунку 811 «Виплати, пов'язані з оплатою праці», попередньо здійснивши їх класифікацію залежно від мети, поставленої керівництвом [28, с. 459]. На переконання авторів, це дасть можливість краще здійснювати контроль над виконанням плану виробництва, збільшити продуктивність праці та раціонально здійснювати розподіл коштів на оплату праці за виконану роботу.

Вважаємо, що пропозиції щодо введення і використання субрахунків першого-третього порядку є виправданими.

Деталізація субрахунків забезпечить проведення ретельного, послідовного аналізу витрат на оплату праці, що дасть можливість здійснювати коригування фонду оплати праці, встановити вплив факторів на його зміни та визначити напрями підвищення продуктивності праці.

Але необхідно враховувати усі об'єктивні чинники: вид діяльності, договірне регулювання оплати праці, складові фонду оплати праці, витрати на мотивацію праці тощо.

\section{4. Висновки}

Спеціалісти, які займаються обліком та оподаткуванням всіх виплат працівникам постійно стикаються з певними складнощами в обліку та оподаткування таких виплат, адже нормативно-правове регулювання обліку та оподаткування виплат працівникам постійно змінюються. Тож, до проблем обліку та оподаткування розрахунків за виплатами працівникам на підприємстві слід віднести наступні: постійні зміни законодавства; мінливий склад виплат за категоріями; певні відмінності між П(С)БО 26 «Виплати працівникам» та МСБО 19 «Виплати працівникам»; зміни ставок оподаткування; зміни складу виплат, які оподатковуються, а які не підлягають оподаткуванні; відсутність мотивування виплати всіх видів виплат офіційно; складнощі у відображенні певних видів виплат, які мало розкриті у П(С)БО 26 «Виплати працівникам»; суперечливість та чисельні недоліки трудового законодавства України; відсутність ефективних систем податкових пільг на виплати працівникам; низький рівень соціальної пільги; високий податковий тягар [15]. 
Заробітна плата нині виконує не властиві йй визначені функції (відтворювальну, стимулюючу, регулюючу, соціальну), а інші: збереження зайнятості, запобігання безробіттю ціною заниження заробітної плати; забезпечення соціальних гарантій; збереження попереднього статусу, пов'язаного із попереднім робочим місцем; стримування інфляції (шляхом заборгованості із заробітної плати); перерозподіл зайнятих за галузями і сферами економіки; поширення нелегальної діяльності та вторинної зайнятості; посилення мобільності робочої сили [10, с. 266].

Вище викладений матеріал підтверджує актуальність та проблематику дослідження. У підходах до пошуку шляхів удосконалення обліку заробітної плати слід виходити із ії сутності як складної багаторівневої системи, враховувати практику та проблеми обліку, зважати на необхідність зменшення податкового навантаження на фонд оплати праці та суми «тіньових» заробітних плат.

\section{Список літератури:}

1. Воськало Н.М., Воськало В.І. Теоретичні та методологічні основи розрахунків за виплатами працівникам. Східна Свропа: економіка, бізнес та управління. 2018. Вип. 2. С. 239-244.

2. Глухова С.В., Зотова А.А. Підходи до сутності заробітної плати. Молодий вчений. 2016. № 12.1. С. 698-701.

3. Головачова А.О. Розмежування понять «заробітна плата» та «оплата праці». Збірник наукових пращь ХНПУ ім. Г.С. Сковороди. 2014. Випуск 22. С. 84-88.

4. Доходи державного бюджету України; Доходи зведеного бюджету України. URL: https://index.minfin.com.ua/ua/finance/budget/gov/income (дата звернення: 05.05.2020).

5. Державна казначейська служба. URL: https://www.treasury.gov.ua/ua (дата звернення: 05.05.2020).

6. Інструкція зі статистики заробітної плати: Наказ Держкомстату України від 13.01.2004 р. № 5. URL: https://zakon.rada.gov.ua/laws/show/z0114-04 (дата звернення: 05.05.2020).

7. Інструкція про застосування плану рахунків бухгалтерського обліку активів, капіталу, зобов'язань і господарських операцій підприємств та організацій: Наказ Міністерства фінансів України від 30.11.1999 р. № 291. URL: http://zakon0.rada.gov.ua/laws/show/z0893-99 (дата звернення: 05.05.2020).

8. Кодекс законів про працю України від 01.06.1972. URL: https://zakon.rada.gov.ua/laws/show/322-08 (дата звернення: 05.05.2020).

9. Костишина Т.А., Степанова Л. Оплата праці як складова соціальної політики держави. Економіка і організація управління. 2016. № 3(23). С. 66-72. 
10. Лисак В.Ю. Сутність заробітної плати та іï значення в процесі економічного управління підприємством. Економіка $i$ суспільство. 2016. Випуск № 4. С. 264-269.

11. Мельник Т.Г. Теоретичні підходи до системи обліку та аналізу розрахунків з оплати праці. Управління розвитком. 2010. № 2(78). С. 121-124.

12. Мінімальна заробітна плата, Прожитковий мінімум. URL: https://index.minfin.com.ua/ua/labour/salary/min/ (дата звернення: 05.05.2020).

13. Овсюк Н.В. Сутність та особливості понять «оплата праці» та «заробітна плата» визначених в нормативно-правовій базі України. Вісник Хмельницького національного університету. 2014. № 3. Т. 2. С. 27-31.

14. Островерха Р.Е. Теоретичні засади удосконалення організації обліку заробітної плати. Вісник начіонального наукового університету «Львівська політехніка». Менеджмент та підприємниитво в Україні: етапи становлення і проблеми розвитку. 2014. № 797. C. 284-291. URL: http://nbuv.gov.ua/ UJRN/VNULPM_2014_797_41 (дата звернення: 05.05.2020).

15. Очеретько Л.М., Хохлова І.А. Проблеми обліку та оподаткування розрахунків за виплатами працівникам і шляхи їх вирішення. Ефективна економіка. 2018. №10. URL: www.ekonomy.nayka.com.ua (дата звернення: 05.05.2020).

16. Податковий кодекс № 2755-XVII від 01.01 .2018 p. URL: http://zakon4.rada.gov.ua (дата звернення: 05.05.2020).

17. Подолянчук О.А. Облік заробітної плати та іï оподаткування. Удосконалення обліку, контролю, аудиту, аналізу та оподаткування в сучасних умовах інтеграційних процесів у світовій економіці : тези доповідей III Міжнародної науково-практичної конференції (м. Ужгород, 18-19 квітня 2018 р.). Ужгород : Видавництво УжНУ «Говерла», 2018. С. 101-104.

18. Положення (стандарт) бухгалтерського обліку 26 «Виплати працівникам»: Наказ Міністерства фінансів України від 28.10.2003 p. № 601. URL: http://zakon2.rada.gov.ua/laws/show/z1025-03 (дата звернення: 05.05.2020).

19. Про відпустки: Закон України від 15.11 .1996 р. № 504/96-ВР. URL: https://zakon2.rada.gov.ua/laws/show/504/96-\%D0\%B2\%D1\%80 (дата звернення: 05.05.2020).

20. Про затвердження Порядку обчислення середньої заробітної плати: Постанова Кабінету міністрів України від 08.02.1995 № 100 . URL: http://zakon.rada.gov.ua (дата звернення: 05.05.2020).

21. Про збір та облік єдиного внеску на загальнообов'язкове державне соціальне страхування: Закон України від 08.07.2010 p. № 2464-VI. URL: https://zakon.rada.gov.ua/laws/show/2464-17 (дата звернення 05.05.2020).

22. Про оплату праці: Закон України від 01.05.1995. № 108/95-ВР. URL: http://zakon.rada.gov.ua (дата звернення: 05.05.2020).

23. Про прожитковий мінімум: Закон України від 15.07.1999 р. № 966-XIV. URL: http://zakon3.rada.gov.ua/laws/show/966-14 (дата звернення: 05.05.2020).

24. Про основні показники зі сплати єдиного соціального внеску за 2019 рік. URL: http://www.fpsu.org.ua/napryamki-diyalnosti/sotsialne-strakhuvannya-i-pensijne-zabezpechennya/17421-pro-osnovni-pokazniki-zi-splati-edinogo-sotsialnogovnesku-za-2019-rik.html (дата звернення: 05.05.2020). 
25. Селіванова Н.М., Ветренюк Б.Б. Сучасні проблеми обліку оплати праці та шляхи їх вирішення. URL: http:/dspace.opu.ua/jspui/ bitstream/123456789/6217/1/95.pdf (дата звернення: 05.05.2020).

26. Середня заробітна плата за видами економічної діяльності за місяць: Статистична інформація станом на 30.03.2020 p. URL: http://www.ukrstat.gov.ua/ (дата звернення: 05.05.2020).

27. Тибінка Г.І. Організаційно-економічний механізм регулювання оплати праці в господарській системі України: дисертація на здобуття наук. ступеня к.е.н. спеціальності 08.00.03 - економіка та управління національним господарством. Львівський національний університет ім. І. Франка. 2014. 244 с.

28. Томчук О.Ф., Машевська А.А. Контроль та управління витратами на оплату праці. Інфраструктура ринку. 2018. Вип. 17. С. 457-461.

\section{References:}

1. Vos'kalo, N. M., \& Vos'kalo, V. I. (2018). Teoretychni ta metodolohichni osnovy rozrakhunkiv za vyplatamy pratsivnykam [Theoretical and methodological bases of calculations for payments to employees]. Europe: Economy, Business and Management, no. 2, pp. 239-244.

2. Hlukhova, S. V., \& Zotova, A. A. (2016). Pidkhody do sutnosti zarobitnoyi platy[Approaches to the essence of wages]. A young scientist, no. 12, pp. 698-701.

3. Holovachova, A. O. (2014). Rozmezhuvannya ponyat' "zarobitna plata» ta «oplata pratsi» [Distinguishing between the concepts of "wages" and "pay for work"]. Collection of scientific works of KhNPU by H.S. Skovoroda, vol. 22, pp. 84-88.

4. Dokhody derzhavnoho byudzhetu Ukrayiny; Dokhody zvedenoho byudzhetu Ukrayiny [Revenues of the state budget of Ukraine; Revenues of the consolidated budget of Ukraine]. Retrived from: https://index.minfin.com.ua/ua/finance/budget/ gov/income (accessed 5 May 2020).

5. Derzhavna kaznacheys'ka sluzhba [State Treasury Service]. Retrieved from: https://www.treasury.gov.ua/ua (accessed 5 May 2020).

6. Instruktsiya zi statystyky zarobitnoyi platy: Nakaz Derzhkomstatu Ukrayiny vid 13.01.2004 r. №5 [Instruction on wage statistics: Order of the State Statistics Committee of Ukraine dated 13.01.2004 № 5]. Retrieved from: https://zakon.rada.gov.ua/laws/show/z0114-04 (accessed date 05.05.2020).

7. Instruktsiya pro zastosuvannya planu rakhunkiv bukhhalters'koho obliku aktyviv, kapitalu, zobov"yazan' i hospodars'kykh operatsiy pidpryyemstv ta orhanizatsiy: Nakaz Ministerstva finansiv Ukrayiny vid 30.11.1999 r. № 291 [Instruction on the application of the chart of accounts for accounting of assets, capital, liabilities and business operations of enterprises and organizations: Order of the Ministry of Finance of Ukraine dated 30.11.1999 № 291]. Retrieved from: http://zakon.rada.gov.ua/laws/show/z0893-99 (accessed 5 May 2020).

8. Kodeks zakoniv pro pratsyu Ukrayiny vid 01.06.1972 [Code of Labor Laws of Ukraine of June 1, 1972]. Retrieved from: https://zakon.rada.gov.ua/laws/ show/322-08 (accessed 5 May 2020). 
9. Kostyshyna, T. A., \& Stepanova, L. (2016). Oplata pratsi yak skladova sotsial'noyi polityky derzhavy [Remuneration as a component of social policy]. Economics and organization of management, no. 3(23), pp. 66-72.

10. Lysak, V. Yu. (2016). Sutnist' zarobitnoyi platy ta yiyi znachennya v protsesi ekonomichnoho upravlinnya pidpryyemstvom [The essence of wages and its importance in the process of economic management of the enterprise]. Economy and society, vol. 4, pp. 264-269.

11. Mel'nyk, T. H. (2010). Teoretychni pidkhody do systemy obliku ta analizu rozrakhunkiv z oplaty pratsi [Theoretical approaches to the system of accounting and analysis of payroll]. Management of development, no. 2(78), pp. 121-124.

12. Minimal'na zarobitna plata, Prozhytkovyy minimum [Minimum wage, subsistence level]. Retrieved from: https://index.minfin.com.ua/ua/labour/salary/min/. (accessed 5 May 2020).

13. Ovsyuk, N. V. (2014). Sutnist' ta osoblyvosti ponyat' «oplata pratsi» ta «zarobitna plata» vyznachenykh v normatyvno-pravoviy bazi Ukrayiny [The essence and features of the concepts of "wages" and "payment for work" defined in the regulatory framework of Ukraine]. Bulletin of Khmelnytsky National University, no. 3, vol. 2, pp. 27-31.

14. Ostroverkha, R. E. (2014). Teoretychni zasady udoskonalennya orhanizatsiyi obliku zarobitnoyi platy [Theoretical principles of improving the organization of payroll]. Visnyk natsional'noho naukovoho universytetu "L'vivs'ka politekhnika». Menedzhment ta pidpryyemnytstvo $v$ Ukrayini: etapy stanovlennya i problemy rozvytku (electronic journal), no. 797. pp. 284-291. Retrieved from: http://nbuv.gov.ua/ UJRN/VNULPM_2014_797_41 (accessed 5 May 2020).

15. Ocheret'ko, L. M., \& Khokhlova, I. A. (2018). Problemy obliku ta opodatkuvannya rozrakhunkiv za vyplatamy pratsivnykam i shlyakhy yikh vyrishennya [Problems of accounting and taxation of payments to employees and ways to solve them]. Efectyvna economika (electronic journal), no. 10. Retrieved from: www.ekonomy.nayka.com.ua (accessed 5 May 2020).

16. Podatkovyy kodeks №2755-XVII vid 01.01.2018 r [Tax Code № 2755-XVII dated 01.01.2018]. URL: http://zakon4.rada.gov.ua (accessed 5 May 2020).

17. Podolyanchuk, O. A. (2018). Oblik zarobitnoyi platy ta yiyi opodatkuvannya. Udoskonalennya obliku, kontrolyu, audytu, analizu ta opodatkuvannya v suchasnykh umovakh intehratsiynykh protsesiv u svitoviy ekonomitsi [Wage accounting and taxation. Improving accounting, control, audit, analysis and taxation in modern conditions of integration processes in the world economy]. Proceedings of the III Mizhnarodnoyi naukovo-praktychnoyi konferentsiyi (Uzhhorod, 18-19 April 2018 r.). Uzhhorod: Vydavnytstvo UzhNU «Hoverla», pp.101-104.

18. Polozhennya (standart) bukhhalters'koho obliku 26 «Vyplaty pratsivnykam»: Nakaz Ministerstva finansiv Ukrayiny vid 28.10.2003 № 601 [On the collection and accounting of a single contribution to the obligatory state social insurance: Law of Ukraine of 08.07.2010 642464-VI]. Retrieved from: http://zakon2.rada.gov.ua/ laws/show/z1025-03 (accessed 5 May 2020).

19. Pro vidpustky: Zakon Ukrayiny vid 15.11.1996 r. №504/96-VR [On leave: Law of Ukraine of 15.11.1996 № 504/96-VR]. Retrieved from: https://zakon2.rada.gov.ua/ laws/show/504/96-\%D0\%B2\%D1\%80 (accessed 5 May 2020). 
20. Pro zatverdzhennya Poryadku obchyslennya seredn'oyi zarobitnoyi platy: Postanova Kabinetu ministriv Ukrayiny vid 08.02.1995 № 100 [On approval of the Procedure for calculating the average salary: Resolution of the Cabinet of Ministers of Ukraine of 08.02.1995 № 100]. Retrieved from: http://zakon.rada.gov.ua (accessed 5 May 2020).

21. Pro zbir ta oblik yedynoho vnesku na zahal'noobov"yazkove derzhavne sotsial'ne strakhuvannya: Zakon Ukrayiny vid 08.07.2010 r. № 2464-VI [On the collection and accounting of a single contribution to the obligatory state social insurance: Law of Ukraine of 08.07.2010 642464-VI]. Retrieved from: https://zakon.rada.gov.ua/laws/show/2464-17 (accessed 5 May 2020).

22. Pro oplatu pratsi: Zakon Ukrayiny vid 01.05.1995. № 108/95-VR [On the collection and accounting of a single contribution to the obligatory state social insurance: Law of Ukraine of 08.07.2010 642464-VI]. Retrieved from: https://zakon.rada.gov.ua/laws/show/2464-17 (accessed 5 May 2020).

23. Pro prozhytkovyy minimum: Zakon Ukrayiny vid 15.07.1999 r. № 966-XIV [On the subsistence level: Law of Ukraine of 15.07.1999 № 966-XIV]. URL: http://zakon3.rada.gov.ua/laws/show/966-14 (accessed 5 May 2020).

24. Pro osnovni pokaznyky zi splaty yedynoho sotsial'noho vnesku za 2019 [On the main indicators for the payment of the single social contribution for 2019]. Retrieved from: http://www.fpsu.org.ua/napryamki-diyalnosti/sotsialne-strakhuvannya-i-pensijne-zabezpechennya/17421-pro-osnovni-pokazniki-zi-splati-edinogo-sotsialnogo-vnesku-za-2019-rik.html (accessed 5 May 2020).

25. Selivanova, N. M., \& Vetrenyuk, B. B. (2020). Suchasni problemy obliku oplaty pratsi ta shlyakhy yikh vyrishennya [Modern problems of payroll accounting and ways to solve them]. Retrieved from: http://dspace.opu.ua/jspui/bitstream/ 123456789/6217/1/95.pdf (accessed 5 May 2020).

26. Serednya zarobitna plata za vydamy ekonomichnoyi diyal'nosti za misyats': Statystychna informatsiya stanom na 30.03.2020 [Average wages by type of economic activity per month: Statistical information as of 30.03.2020]. Retrieved from: http://www.ukrstat.gov.ua/ (accessed 5 May 2020).

27. Tybinka, H. I. (2014). Orhanizatsiyno-ekonomichnyy mekhanizm rehulyuvannya oplaty pratsi $\mathrm{v}$ hospodars'kiy systemi Ukrayiny [Organizational and economic mechanism of wage regulation in the economic system of Ukraine] (PhD Thesis), Lviv: L'viv natsional university by I. Franko.

28. Tomchuk, O. F., \& Mashevs'ka, A. A. (2018). Kontrol' ta upravlinnya vytratamy na oplatu pratsi [Control and management of labor costs]. Market infrastructure, no. 17, pp. 457-461. 